\title{
The impact of board diversity and voluntary risk disclosure on financial outcomes. A case for the manufacturing industry
}

\author{
Nuria Reguera-Alvarado and Francisco Bravo-Urquiza \\ Department of Accounting and Financial Economy, \\ University of Seville, Sevilla, Spain
}

Voluntary risk disclosure on financial outcomes

\begin{abstract}
Purpose - The purpose of this paper is to analyse how board diversity affects firm financial outcomes through the way in which this diversity helps to improve voluntary disclosures.

Design/methodology/approach - The partial least squares (PLS) technique is used, and a sample of the manufacturing firms listed in Standard and Poor's 500 for 2009 is studied. In relation to board diversity, two specific characteristics are considered, namely, gender diversity and ethnic diversity. Content analysis techniques are used to measure risk disclosures.
\end{abstract}

Findings - The results show that there is a positive association between board diversity and firms' financial outcomes, which is explained by disclosing risk information.

Research limitations/implications - The results indicate that the effect of boards of directors on firm outcoumes is influenced by the board involvement in specific strategies, thereby providing encouraging opportunities for future research.

Practical implications - These findings have implications both for companies, when selecting board members, and for policymakers, when establishing requirements concerning board composition. Moreover, the evidence highlights the role of disseminating risk information, which has direct implications for managers and regulators, who may better understand the value-relevance of risk disclosures.

Originality/value - The use of PLS technique is one of the novelties of this paper. The novelty of this approach provides fresh insights into the literature, highlighting that the effect of boards on firm outcomes may be mediated by director involvement in specific disclosure strategies.

Keywords Board of directors, Gender diversity, Board diversity, Ethnic diversity,

Financial outcomes, Risk disclosures

Paper type Research paper

\section{Introduction}

Understanding how a board of directors actually functions and how boards may contribute to financial outcomes has generated major research interest for some time now, and the corporate governance literature has highlighted the key role played by board effectiveness in firms' success. In particular, board diversity has gained significant attention from researchers, investors and policymakers (Mensi-Klarbach, 2014; Lending and Vähämaa, 2017) and has become a priority in most countries with regard to improving the governance of firms. As a result, there is an ongoing debate concerning whether board diversity actually

The authors acknowledge the Spanish Ministry of Economy and Competitiveness for financial support (Project ECO2015-69637-R).

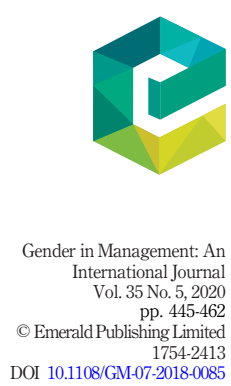


GM

35,5

leads to value creation (Kılıç and Kuzey, 2016; Gordini and Rancati, 2017). However, despite the growing importance of diversity, the literature has generally failed to consider how more diverse boards may have a positive financial impact. In this paper, we merge two branches of literature to provide an explanation as to why board diversity might lead to positive financial outcomes. In particular, the relationship between board diversity and firm financial outcomes may be explained because boards that are more diverse help to improve disclosure practices. A number of studies support the notion that boards are responsible for the information published in annual reports (Li et al., 2008) and that directors can help to disclose relevant information to all stakeholders (Pucheta-Martínez et al., 2016). In addition, a major stream of the literature has shown that voluntary disclosure practices may have positive effects on financial outcomes (Lamber et al., 2012; Plumlee et al., 2015).

The main objective of this paper is to examine whether board diversity leads to positive financial outcomes arising from the voluntary disclosure of specific risk information. To that end, we study the direct effects of board diversity on firm financial outcomes and the mediated effects of voluntary risk disclosures. This question remains a controversial business issue, with relevant implications in various research areas such as strategic management, business ethics or firm governance. Our sample comprises all the companies in the manufacturing industry classification listed in Standard and Poor's 500 for 2009. The manufacturing sector has been chosen because of the high impact that this industry has on the US market. Moreover, in 2009, risk exposure was particularly high for this industry, with risk information proving vital to investors. A number of studies have posited that risk reporting may significantly influence capital markets, especially in periods of financial crisis (Abraham and Cox, 2007; Cabedo and Tirado, 2016). In particular, in 2009 several US agencies encouraged firms to disclose more risk information. For example, the Committee of Sponsoring Organizations of the Treadway Commission (COSO) (2009) highlights that risks form part of everyday business and organisational strategy and that, as a result, firms must be prepared to manage and communicate information on risks. In October 2009, the National Association of Corporate Directors (NACD) (2009) also underlined that firms' reporting practices should consider the importance of providing different perspectives on risks, including comprehensive risk information beyond what are merely quantitative models. At the same time, this association provided guidance for boards with regard to monitoring potential company risks and developing effective communication of such risks. In addition, the Securities Exchange Commission (SEC Release 33-9089, 2009) proposed enhancing disclosures concerning companies' risk oversight practices and underlined the role played by boards of directors in risk disclosure strategy. Therefore, this provides an interesting scenario to better understand the role of board diversity. Specifically, we focus on two main aspects of diversity: gender and ethnicity. Both attributes remain particularly relevant in the US context and were explicitly considered by US regulators in 2009 (SEC Release 33-9089). This rule required public companies to provide disclosure of the extent to which board diversity is considered in the director nomination process, by assuming that investors attach importance to board diversity.

In relation to measures of voluntary risk disclosures, a content analysis was conducted over the whole sample and each annual report was manually examined and coded. To achieve our objective, partial least squares (PLS) was used, as it proves a suitable method for examining mediation effects between variables. Use of PLS implies a step forward in the literature because it allows a set of relationships between one or more independent variables and one or more dependent variables to be examined in a comprehensive model.

Our research contributes to the literature in several ways. First, as do many previous studies, we confirm that board diversity leads to positive firm outcomes. In particular, we extend the prior evidence by showing that the positive effects of board diversity may be 
explained by the disclosure of risk information. These results confirm that board diversity is not solely an ethical issue and contribute to the debate surrounding why diversity matters. This evidence has direct implications for board member selection for firms and policymakers alike. Furthermore, we provide information on the impact of risk disclosures in the manufacturing industry in a context of a high-risk exposure. These findings enable firms and regulators to better understand the importance of this kind of information. In addition, unlike existing studies, the empirical approach adopted in this paper innovates by using PLS technique. The application of this method provides an important insight into the literature, highlighting that the effect of boards of directors on firm outcomes may be mediated by board involvement in specific strategies.

\section{The US context: the manufacturing industry, risk disclosures and board diversity}

The manufacturing industry has traditionally made a decisive contribution to gross domestic product (GDP) growth in the USA[1] and has become extremely important as it provides high-wage jobs, commercial innovation and is key to reducing trade deficit (Helper et al., 2012). However, the destructive global effect of the financial crisis became particularly clear in 2009 for US manufacturing industries. The manufacturing sector often faces a wide range of risk factors (Linsley and Shrives, 2006; Dobler et al., 2011). In the USA, a number of risks are associated with this industry such as domestic and overseas supplier problems, distribution disruptions, federal, state and/or local legislation, labour concerns, commodity and raw material prices, competition, threats to international operations and the ability to innovate to meet changing customer needs, among others. The year 2009 was a particularly significant period that witnessed major stock market decline and volatility, coupled with general economic conditions that rendered the manufacturing sector more vulnerable to risk. According to Ernst and Young (2009), the risks for global business in 2009 that might have accentuated the risk exposure of manufacturing firms concerned the credit crunch, the deepening recession, cost cutting, as well as regulations and compliance. Generally speaking, periods of financial crisis and high-risk exposure tend to exacerbate agency conflicts in capital markets and stakeholders' information demands and may make listed firms place greater emphasis on risk disclosure (Abraham and Cox, 2007).

In relation to risk disclosures in the USA and as mentioned in the introduction, during 2009 several agencies expressed major concern regarding how companies should manage risk information and highlighted the need for boards of directors to understand the risks associated with firms and encouraged them to convey such risks effectively (COSO, 2009; NACD, 2009; SEC, 2009). Empirical evidence shows that risk disclosure tends to be greater in the USA compared to other countries, possibly because of the regulatory action taken in this regard (Dobler et al., 2011; Kravet and Muslu, 2013). However, in line with the previous regulations, academics in the US context have also advocated the need to improve risk disclosure practices in capital markets, as this kind of information has been seen to prove useful to US investors, who include it in their valuation models (Campbell et al., 2014). Indeed, other US studies have indicated that risk disclosures affect stock return volatility and trade volume (Kravet and Muslu, 2013).

In addition, board diversity has attracted much attention in the USA. In the US scenario, women and minorities represent a large proportion of the workforce and this inevitably generates a debate vis-à-vis their presence in top business positions and specifically with regard to the inclusion of female directors and ethnic minorities in the boardroom (Erhardt et al., 2003; Carter et al., 2010). Indeed, in the USA, there is particular sensitivity about the issue of diversity given the demographics of both the labour and consumer markets and

\section{Voluntary risk disclosure on financial outcomes}


GM

35,5

much of the research on board diversity has originated from the US context (Carter et al., 2003; Walt and Ingley, 2003), although this has now become an international trend. Although large US firms have recently shown sensitivity toward this issue and expressed a commitment to consider board diversity (Fairfax, 2010), figures still indicate that women and ethnic minorities remain underrepresented in boards (Sappal, 2016; Li et al., 2017). This debate has reached the political sphere, and in 2009, the SEC adopted specific rules requiring listed companies to disclose whether and how board diversity is considered in the director nominee selection process (SEC Release 33-9089, 2009). Specifically, these rules demanded ethnic and gender diversity of boards, which were felt to be key board characteristics for enhancing governance mechanisms. Particularly, firms must indicate whether the nominating committee or the board has "a policy with regard to the consideration of diversity in identifying director nominees", "how this policy is implemented" and "how the nominating committee (or the board) assesses the effectiveness of its policy".

Although board diversity may be explained by moral reasons, many US studies claim that boards that are more diverse can also have a significant impact on organisational outcomes. In this regard, though the influence of diverse boards on firm performance remains unclear (Carter et al., 2010; Bernile et al., 2018), a number of studies in the USA have shown that board diversity influences particular corporate strategies. For instance, researchers have extensively proven that diverse boards are more likely to improve social and environmental practices (Bear et al., 2010; Hafsi and Turgut, 2013; Harjoto et al., 2015; Li et al., 2017). Other authors indicate that board diversity exerts a positive influence on reporting policies (Gul et al., 2011; Srinidhi et al., 2011) and audit quality (Lai et al., 2017). In addition, board diversity may also have an effect on specific decisions concerning merger and acquisitions (Levi et al., 2014) and innovation (Quintana-García and Benavides-Velasco, 2016).

\section{Literature review and hypothesis development}

\subsection{Board diversity and financial outcomes}

Consistent with the situation in the USA, the call for ethnic and gender diversity in boards of directors has become a worldwide concern and there is a growing consensus within the academic community that diversity brings positive effects to a firm in terms of financial outcomes (Terjesen et al., 2016; Hogan and Huerta, 2019). However, the literature has thus far failed to provide conclusive evidence. Because of the multidisciplinary nature of the topic, no single theory can provide a fully comprehensive framework to model the relation between diversity and firm outcome. Theoretically, the link between board diversity and financial outcomes can be explained by agency, resource dependence and stakeholder theories (Gaur et al., 2015; Reguera-Alvarado et al., 2017).

First, the board's function of monitoring and controlling managers is a fundamental concept from agency theory (Jensen and Meckling, 1976). A more diverse board may monitor managers better, as board diversity increases board independence (Carter et al., 2003; Adams and Ferreira, 2009). Gender and etchic minorities can provide the board with members who offer a broad range of experiences, skills and abilities, which are likely to positively affect the effectiveness of its critical function of management control and supervision (Bear et al., 2010). Second, under the resource dependence theory, provision of resources is assumed to be a key director function (Pfeffer and Salancik, 1978). Consistent with this theory, the presence of diverse members helps the firm to build links to its environment, bringing strategic resources to the boards on which directors serve (Walt and Ingley, 2003). Moreover, board diversity yields a greater exchange of more fundamental viewpoints amongst individuals resulting in the ability to consider a broader range of issues and generating better decisions and higher quality ideas (Rhode and Packel, 2010). Third, 
the stakeholder theory suggests that the firm must reflect the interests of all the stakeholders involved in the firm (Freeman, 1984). In this sense, women and ethnically diverse directors offer new perspectives that may allow a board to better understand a firm's environment and to better assess stakeholder needs (Zhang et al., 2013). The presence of diverse directors on a board may therefore engender positive financial outcomes because of a better understanding of the complexities of the environment and different concerns and perspectives taken into consideration in the decision-making process (Carter et al., 2003).

In line with the previous arguments, we posit that board diversity can lead to positive financial outcomes and, hence, the following hypothesis is formulated:

\section{H1. Board diversity leads to positive financial outcomes.}

\subsection{The mediating effect of voluntary risk disclosures}

The theoretical arguments presented explain why board diversity may have a positive financial impact. However, board of director composition per se cannot necessarily be associated with superior financial performance. The effect of board diversity on financial outcomes is likely to be indirect, through the active participation of directors in strategic decisions (Castro et al., 2016). One such decision concerns company policy disclosure, which is expected to have an important impact on capital markets (Lamber et al., 2012; Plumlee et al., 2015). Yet, the effect of information disclosure may depend on the context and type of information (Dutta and Nezlobin, 2017). In this paper, we focus on the disclosure of risk information, which for several reasons, emerges as key in the context analysed. First, the previous literature has generally linked corporate risk disclosures to certain benefits for firms (Cabedo and Tirado, 2004; Linsley and Shrives, 2006; Moumen et al., 2015). As explained in the previous section, in our scenario, manufacturing firms were exposed to great risks and were under stronger regulatory and social pressure to disclose risk information. As a result, risk disclosures are expected to be highly valued by all stakeholders.

In this paper, we aim to answer the following question: Does board diversity affect the voluntary disclosure of risk information and therefore influence firms' financial outcomes? The existing literature on board diversity and voluntary disclosure is limited. Specifically, the evidence on board diversity and risk disclosure is very scarce. Though some studies have found that the quantity of risk information disclosed by firms may be influenced by the proportion of women on the board (Allini et al., 2016) and the percentage of non-white directors (Ntim et al., 2013), other studies suggest a negative association between board gender composition and the various measures adopted for the disclosure of non-financial risks. From a theoretical point of view, boards are responsible for voluntary disclosure practices in annual reports and must be aware of the need to disclose relevant information for capital market agents (Abraham and Cox, 2007). From an agency perspective, directors from diverse backgrounds tend to be more independent and are less likely to be beholden to managers (Adams and Ferreira, 2009; Carter et al., 2010). Heterogeneous groups face more pressure to conform to groupthink, thus favouring closer monitoring of disclosure practices (Upadhyay and Zeng, 2014). In addition, consistent with a resource dependence view, greater director diversity can bring critical resources to a firm, including different ideas, knowledge, experiences and business contacts (Westphal and Bednar, 2005). These heterogeneous resources can facilitate a better appreciation of the complexities of the organisation's external environment. The decision-making process in the boardroom is thus expected to improve, thereby enhancing disclosure practices (Carter et al., 2003). Moreover, in line with the stakeholder theory, disclosing information can be used by directors as part of the dialogue between a firm and its stakeholders (Adams and McNicholas, 2007). 
GM

35,5

Diversity may improve board effectiveness and corporate decisions by increasing boards' ability to perceive stakeholder demands (Miller and Triana, 2009). In particular, diverse boards may be more sensitive to stakeholder information needs and more likely to disclose relevant information for these stakeholders to satisfy their concerns (Nielsen and Huse, 2010).

In line with these arguments, we posit that board diversity may influence disclosure practices by improving voluntary risk disclosure. Furthermore, this improvement in risk disclosure may lead to positive financial outcomes. Therefore, the following hypothesis is formulated:

H2. The relationship between board diversity and financial outcomes is mediated by voluntary risk disclosures.

\section{Data and methodology}

\subsection{Sample and data}

The study sample comprised the companies included in Standard and Poor's 500 Index in 2009 in the manufacturing industry. The year 2009 was selected because it provides an interesting scenario to examine the role of board diversity in risk disclosures, as several rules and recommendations in the USA stressed the need for boards of directors to consider both diversity between their members and risk management strategy (COSO, 2009; NACD, 2009; SEC, 2009). Content analysis techniques were performed to measure voluntary risk disclosures. All the voluntary annual reports of every company included in the sample were read and analysed. Manual analysis contributes to an increased quality of results, as it allows disclosures to be fully understood by considering the whole context and reduces the problems inherent in machine-based procedures with regard to identifying and interpreting risk information (Beattie and Thompson, 2007).

Data regarding directors was obtained from the Investor Responsibility Research Center. A total of 933 directors were studied. Company data were extracted from Compustat. The final sample contained 90 manufacturing firms, which is similar in size to recent studies that use content analysis techniques (Jindal and Kumar, 2012; Castilla-Polo and Ruiz-Rodríguez, 2017; Neifar and Jarboui, 2017). Moreover, PLS models enable guaranteeing reliable results using smaller samples (Reinartz et al., 2009; Jabeen and Faisal, 2018).

\subsection{Variables}

4.2.1 Board diversity. To capture board diversity (BD), we focus on two observable characteristics specifically considered in the USA by the Securities Exchange Commission (SEC Release 33-9089, 2009): ethnic background and gender. In PLS model, board diversity is thus a composite construct that measures board member diversity with regard to these two features.

Specifically, we define diversity as the degree of heterogeneity among board members with respect to ethnicity or gender, using Blau's index, which is widely used in governance research. GENDER is the heterogeneity index for gender with two categories: male and female (Gordini and Rancati, 2017). ETHNICITY is the heterogeneity index for race and contains five categories (Harjoto et al., 2015): Asian, black, Caucasian, Hispanic and Native American. The indicators (manifest variables) model board diversity as a formative construct.

4.2.2 Risk disclosure. This paper focuses on voluntary risk disclosures (RD) in firms' annual reports, measured using a modelled reflective construct. Consistent with the 
literature on disclosure and with risk disclosure studies (Abraham and Cox, 2007; Hassan, 2014), the sentence is considered as the unit of analysis in this paper. The definition provided by Linsley and Shrives (2006, p. 389) is adopted in this paper to identify riskrelated sentences in annual reports. These authors refer to risk disclosures as "any opportunity or prospect, or of any hazard, danger, harm, threat or exposure, that has already impacted upon the company or may impact upon the company in the future or of the management of any such opportunity, prospect, hazard, harm, threat or exposure".

Taking into consideration the framework proposed in the previous literature (Beretta and Bozzolan, 2008), we use three measures to capture risk disclosures: level of information, coverage and dispersion. First, the level of risk disclosures is calculated through the number of sentences containing risk information (Linsley and Shrives, 2006; Dobler et al., 2011; Hassan, 2014). Furthermore, researchers have designed self-constructed disclosure indices based on coverage of information disclosed by companies as a proxy for the quality of voluntary disclosure in general or specific disclosures, in particular, such as risk disclosures (Hassan, 2009; Oliveira et al., 2013). As a second measure, a disclosure index to capture the coverage of risk disclosures is therefore used. Following the framework presented by Dobler et al. (2011) based on prior studies (Cabedo and Tirado, 2004; Linsley and Shrives, 2006) and a review of regulations, this index comprises eight categories. These categories include both financial information (liquidity, credit, results and market) and non-financial information (operation, business, strategy and regulation). This coverage index was obtained by dividing the number of information categories a company disclosed by the total number of categories a company may disclose. Finally, information dispersion can also be associated with the quality of the information disclosed by a company. Quality of information is assumed to be greater when a large amount of information is published on each topic rather than only a few information units about certain topics being disclosed (Beretta and Bozzolan, 2008; Satta et al., 2015). Following Beretta and Bozzolan (2008)[2], a dispersion index, which refers to how concentrated disclosed items are and corresponds to the standardised entropy index, was calculated.

To draw valid inferences, it is important for the coding procedure to be reliable. Therefore, the main criteria for the coding process were initially discussed by the two researchers to minimise ambiguity (Linsley and Shrives, 2006). In addition, this paper uses both stability and reproducibility tests to check the reliability of forward-looking disclosures. The stability test was conducted by one researcher through two rounds of coding of annual reports, performed on different dates. To conduct the reproducibility test, three annual reports were again analysed by these independent researchers. Use of Scott's pi coefficient (Krippendorff, 1980) provided a satisfactory value (0.88).

4.2.3 Financial outcomes. In line with the previous literature, three indicators are used in this paper as financial outcomes (FO): analysts' forecast error, cost of capital and market-tobook ratio. To ensure that these indicators capture the accounting information on risks disclosed in companies' annual reports, they were calculated six months after the financial year end (Wang et al., 2013). First, analysts' forecast error is an important outcome for a firm, as it has traditionally been linked to firm valuation (Garcia-Meca and Sanchez-Ballesta, 2011). In this paper, this error is measured through the absolute value of the median earnings per share forecast by analysts minus the reported earnings per share over the stock market price at the end of the fiscal year (Abernathy et al., 2013). Second, the cost of capital is one of the most important financial outcomes for firms (Lamber et al., 2012). In this paper, we use the inverse of the cost of capital, by assuming that the higher the value of this indicator, the more positive the financial impact. As a proxy for the cost of capital, the measure designed by Easton (2004) is adopted in our paper. This approach has been tested
Voluntary risk disclosure on financial outcomes 
GM

35,5

as a robust measure of the cost of capital that captures a firm's risk and is commonly used in the literature (Hail and Leuz, 2009). Finally, the market-to-book ratio is widely considered a significant financial outcome of a firm related to its performance (Al-Akra and Ali, 2012). This variable was calculated as the ratio of market value to book value. The three measures are modelled so as to manifest indicators of a formative construct called financial outcomes (FO).

Table 1 displays the descriptive statistics of the sample.

\subsection{Research model}

The research model has been tested using a variance-based structural equation modelling technique: PLS. This method is suited to our objective for two main reasons:

(1) the presence of formative indicators (Roldán and Sánchez-Franco, 2012); and

(2) the sample $(n=90)$ is small.

According to Reinartz et al. (2009), when the number of observations is below 250, PLS is highly recommended. Our work uses SmartPLS version 3.0 software.

PLS regression is a highly suitable statistical technique for explanatory applications and iterative procedures using least squares estimation for single- and multi-component models. In the first stage, the scores of the latent constructs are iteratively estimated (the reliability and validity of the measurement model). In the second stage, the final estimates of coefficients (outer weights, loadings and path coefficients) are calculated using ordinary least squares for each partial regression in the model [for a detailed description of the PLS algorithm, see Tenenhaus et al. (2005)].

4.3.1 Validity and reliability of the model. This research uses individual item reliability, construct reliability, convergent validity (Table 2) and discriminant validity (Table 3 ) to assess the measurement model for reflective constructs (Roldán and Sánchez-Franco, 2012). Table 3 shows that:

- all indicators have factor loadings above 0.70; and

- that composite reliabilities are above 0.80. Therefore, the PLS model has internal consistency reliability.

Second, the average variance extracted (AVE) values of over 0.50 also confirm the existence of convergent validity. In Table 3, the traditional Fornell-Larcker criterion confirms the discriminant validity of the model's constructs. It should be noted that as there is only one reflective construct, the Heterotrait-Monotrait ratio of correlations is not applicable.

Table 1.

Descriptive statistics of the variables

\begin{tabular}{lrcccr}
\hline Variable & Mean & Std. deviation & Q1 & Median & Q3 \\
\hline BD1: Gender diversity & 0.264 & 0.109 & 0.193 & 0.278 & 0.337 \\
BD2: Ethnic diversity & 0.160 & 0.135 & 0 & 0.165 & 0.219 \\
RD1: Coverage of information on risks & 0.538 & 0.145 & 0.500 & 0.500 & 0.625 \\
RD2: Dispersion of information on risks & 0.568 & 0.142 & 0.489 & 0.597 & 0.652 \\
RD3: Level of information on risks & 16.700 & 8.519 & 10 & 15 & 20.500 \\
FO1: Analysts forecast error & 0.058 & 0.114 & 0.004 & 0.016 & 0.048 \\
FO2: Inverse cost of capital & 10.324 & 6.327 & & 9.720 & \\
FO3: Market-to-book & 2.342 & 0.183 & 1.187 & 1.670 & 2.895 \\
\hline
\end{tabular}


Item description (construct/indicator)

Variance inflation

BD (Mode B - formative construct)

BD1: Gender diversity

BD2: Ethnic diversity

RD (Mode A - reflective construct)

$\mathrm{RD} 1$ : Coverage of information on risks

RD2: Dispersion of information on risks

RD3: Level of information on risks

FO (Mode B - formative construct)

FO1: Analysts forecast error

FO2: Inverse cost of capital

FO3: Market-to-book factor and CIs

Loading Weight Composite reliability AVE

Note: N.A.: Not applicable
$-0.445$

0.406

1.251

1.079

0.771

0.779

0.89

0.855

0.664

2.425
2.598

1.312

N.A.
Voluntary risk disclosure on financial outcomes

453

Table 2.

N.A. $\quad$ N.A.

\begin{tabular}{lccc}
\hline & $\mathrm{BD}$ & $\mathrm{FO}$ & $\mathrm{RD}$ \\
\hline $\mathrm{BD}$ & $N . A$. & & \\
$\mathrm{FO}$ & 0.265 & N.A. & \\
$\mathrm{RD}$ & 0.302 & 0.453 & 0.815
\end{tabular}

Notes: BD: Board diversity; RD: Risk disclosure; FO: Financial outcomes. The diagonal elements (italics) are the square root of the AVEs; off-diagonal elements are the correlations among constructs. N.A.: Not applicable

Table 3.

Discriminant validity assessment for each model

4.3.2 Global goodness of fit. The goodness of fit (GoF) index is an index that globally validates the PLS model to reach a compromise between the performance of the measurement and that of the structural model (Tenenhaus et al., 2005). GoF is used to determine the overall predictive power of the model by accounting for the performance of both measurement and structural parameters (Chin, 2010). The current study obtained a $\mathrm{GoF}$ value of 0.30 , indicating that the explanatory capacity of the model is powerful and that its path coefficients are stable and robust.

\section{Results}

To evaluate the structural model, this paper uses path coefficients, the $R^{2}$ of endogenous latent variables and standardised root mean square residuals. Additionally, both the bootstrapping procedure with 5,000 resamples (Hair et al., 2011) and the percentile bootstrap 95\% confidence interval (CI) (Chin, 2010) show the statistical significance of the path coefficients (Table 4 and Figure 1). The application of bootstrapping allowed us to test the mediation hypothesis (Hayes et al., 2011). Thus, this work's 5,000 resamples generated 95\% $\mathrm{CI}$ (percentile) for the mediator.

We applied the analytical approach described by Taylor et al. (2008) to test our mediation hypothesis (H2). The indirect effects are specified and contrasted with the mediators (i.e. $\mathrm{RD}$ ) (Table 5). We also examined the total (c) and direct (H1: c') effects of the independent variable (i.e. board diversity) on the dependent variable (i.e. financial outcomes). Following 
GM

35,5

\begin{tabular}{|c|c|c|c|c|c|}
\hline $\begin{array}{l}\text { Effects on } \\
\text { endogenous variables }\end{array}$ & $\begin{array}{c}\text { Theoretical } \\
\text { sense (support) }\end{array}$ & $\begin{array}{c}\text { Direct effect } \\
\text { (path coefficient) }\end{array}$ & $\begin{array}{c}t \text {-value } \\
\text { (bootstrap) }\end{array}$ & $\begin{array}{l}\text { Percentile } \\
95 \% \mathrm{CI}\end{array}$ & $\begin{array}{c}\text { Explained } \\
\text { variance }(\%)\end{array}$ \\
\hline $\begin{array}{l}\mathrm{RD}\left(R^{2}=9.10 \%\right) \\
\mathrm{BD}\left(\mathrm{a}_{1}\right)\end{array}$ & $+($ Yes $)$ & $0.302 * * *$ & $3.367 * * *$ & {$[0.106 ; 0.466] \mathrm{Si}$} & Sig. 9.12 \\
\hline $\begin{array}{l}\mathrm{FO}\left(R^{2}=22.30 \%\right) \\
\operatorname{BD}\left(c^{*}\right) \\
\operatorname{RD}\left(b_{1}\right)\end{array}$ & $\begin{array}{l}+(\text { Yes }) \\
-(\text { Yes })\end{array}$ & $\begin{array}{l}0.14 \\
0.411 * * *\end{array}$ & $\begin{array}{l}1.391 \text { Nsig. } \\
5.274 * * *\end{array}$ & $\begin{array}{l}{[0.008 ; 0.377]} \\
\text { Nsig. } \\
\text { [0.289;0.596] Si }\end{array}$ & $\begin{array}{r}3.71 \\
\text { Sig. } 18.62\end{array}$ \\
\hline
\end{tabular}

Table 4.

Effects on

$\mathrm{RD}\left(\mathrm{b}_{1}\right)$

$-($ Yes $)$

$0.411 * * *$

$5.274 * * *$

Nis.

Notes: BD: Board diversity; RD: Risk disclosure; FO: Financial outcomes. $* p<0.10$; $* * p<0.05$; *** $p<0.01$ $($ based on $\mathrm{t}(4999)$, two-tailed test $) ; \mathrm{t}(0.10 ; 4999)=1.65 ; \mathrm{t}(0.05 ; 4999)=1.96 ; \mathrm{t}(0.01 ; 4999)=2.58$. Sig. denotes a significant direct effect at 0.10.; Nsig. denotes a non-significant direct effect at 0.10

variables for each

PLS model

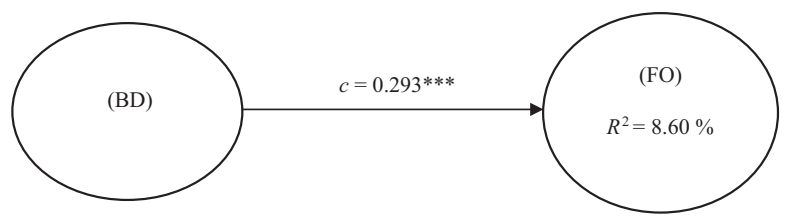

(a)

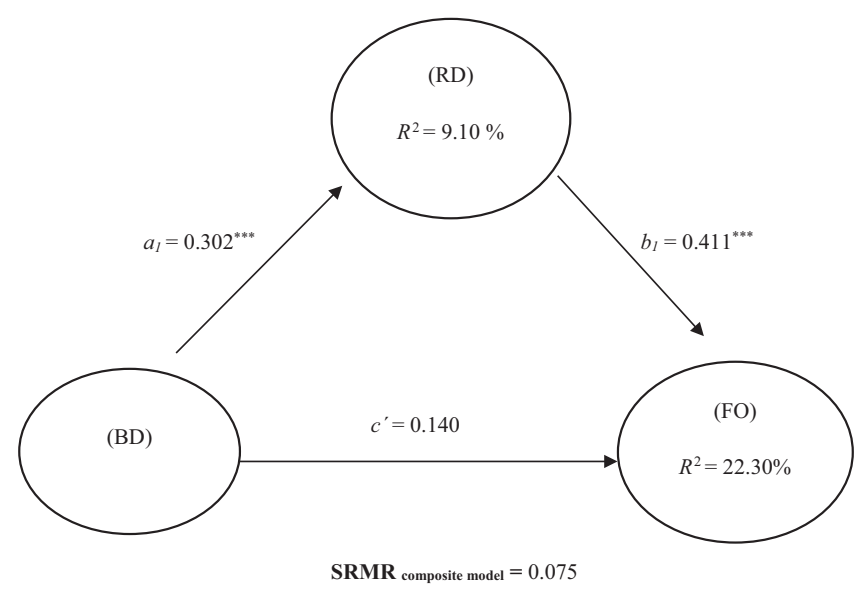

(b)

Figure 1.

Structural model: onepath mediation model
Notes: (a) Model with total effect; (b) model with a three-path mediated effect

$H 1=$ Board diversity $\rightarrow$ Financial outcomes $=\mathrm{c}^{\prime}$

$H 2=$ Board diversity $\rightarrow$ Risk disclosure $\rightarrow$ Financial

outcomes $=$ alb1 $* p<0.10 ; * * p<0.05 ; * * * p<0.01$ 
GM

35,5

the procedure of Williams and MacKinnon (2008), we analysed the mediating role played by $\mathrm{RD}$ in the relationship between the BD and FO. Chin (2010) proposed a two-step procedure for testing mediation in PLS:

(1) use the specific model in question, including both the direct and the indirect paths and perform $\mathrm{N}$ bootstrap resampling and explicitly calculate the product of the direct paths that form the indirect path under assessment; and

(2) estimate the significance using percentile bootstrap (Williams and MacKinnon, 2008).

This generates a 95\% CI for the mediator: $\mathrm{RD}$ (H2). If the interval for a mediation hypothesis does not contain a zero, this means that the indirect effect is significantly different from zero, with $95 \%$ CI. As Figure 1(a) and Table 5 show that the main direct effect of the model is associated with $H 1$ (Board diversity $\rightarrow$ Financial outcomes). The findings show that greater diversity in boards generates a positive and significant total effect on financial outcomes (c $=0.293, p<0.01, R^{2}=8.60 \%$ ). However, when including the mediator [Figure 1(b)], BD no longer has a significant direct effect on FO (H1: c'). This means that RD fully mediates the influence of board diversity on financial outcomes. Indeed, H1 is not supported. Nevertheless, support is found for $H 2$, which means that the indirect effect in our research model is significant. Consequently, this analysis shows that $\mathrm{RD}$ mediates the relationship between $\mathrm{BD}$ and $\mathrm{FO}\left(\mathrm{H} 2\right.$ : $\left.\mathrm{a}_{1} \mathrm{~b}_{1}\right)$. Finally, the magnitude and importance of the indirect effects is estimated. To this end, following Iacobucci and Duhachek (2003), the study uses the variance accounted for (VAF) value, which represents the ratio of an indirect effect to the total effect.

As shown in Table 5, the mediating effect tested here is not statistically significant at the 95\% CI and exerts a substantial mediating influence on the relationship between BD and FO. In contrast, the indirect effect via RD (H2) yields a VAF of $46.97 \%$. As a result, these findings confirm that the BD-FO relationship is partially mediated by $\mathrm{RD}$.

\section{Discussion and conclusions}

In the USA, the manufacturing sector faced a wide range of risk factors in 2009. Moreover, several agencies highlighted the role of boards of directors in the oversight and disclosure of risk information. In particular, the inclusion of women and ethnic minorities was explicitly recommended in that year (SEC, 2009). Given such a scenario, the main objective of the present paper is to ascertain whether board diversity may exert a positive financial impact through the voluntary disclosure of risk information. Although previous studies addressing board composition have tended to single out one dimension of board diversity, this paper underscores the importance of considering the joint effect of gender and ethnic diversity.

Our descriptive results confirm the low proportion of female directors and a significant underrepresentation of ethnic minorities in boards. Furthermore, the need to improve risk disclosure policies is also highlighted. Particularly, the firms analysed disclosed an average of 16.7 sentences on risk information. The coverage index indicates that these sentences dealt with about half of the categories presented for risk information. These sentences mainly focus on non-financial risk information and tend to provide qualitative information about risks related to operations, business, strategy and regulations. The dispersion index confirms that risk information concentrates on non-financial categories. In addition, our results reveal a positive relationship between board diversity and firm financial outcomes. These findings are consistent with the theoretical arguments and confirm the significance of board diversity in the creation of value for firms. In line with recent studies (Gaur et al., 2015), we opt to integrate different theories (i.e. agency, resource dependence and 
stakeholder) to develop hypotheses linking board diversity to firm outcomes. In this sense, board diversity may improve financial outcomes for a number of reasons such as it enhances the board's monitoring function, it provides access to strategic resources for companies and it enables boards to understand better both their environment and their stakeholders' needs. Specifically, our evidence highlights that the relationship between board diversity and financial outcomes should be explained taking into consideration director participation in firms' strategic decisions. In particular, our results show the mediated effect of risk disclosures.

Therefore, we extend the previous literature on the benefits of board diversity (Bear et al., 2010; Terjesen et al., 2016; Gordini and Rancati, 2017) by demonstrating the impact of board diversity on risk disclosure practices. In addition, consistent with prior studies (Lamber et al., 2012; Plumlee et al., 2015) voluntary disclosures are found to influence capital markets. Specifically, risk disclosure appears to benefit firms, a fact which may be explained because risk information helps to reduce information asymmetries and enhance investor confidence.

These findings have direct implications for research, practice and society as a whole. First, this study presents several academic implications. In this regard, our evidence may explain some of the inconclusive results found in previous research and help to better understand the important relationship between board diversity and firm financial outcomes. Particularly, the use of PLS technique provides a relevant framework for academics with regard to how corporate strategies can mediate the relation between boards of directors and firm outcomes, which offers encouraging opportunities for future research into the role played by boards of directors. In addition, the theoretical approach used in this study reinforces the validity of agency theory, resource dependence theory and stakeholder theory in explaining the impact of boards and also as disclosure theories. Second, our paper also has important practical implications for both firms and regulators. On the one hand, it will help managers of companies to understand those aspects related to the configuration of the board of directors that are essential to improve firm outcomes, which can be useful for firms when selecting board members. In particular, beyond the theoretical expectations, our empirical evidence strengthens the importance of board diversity in the creation of value for firms. Further, firms can better understand the effect of their reporting strategies and, specifically, managers will be aware of the relevance of risk disclosure policies. On the other hand, policymakers can also benefit from our results, which highlight the need for boards to consider both board diversity and risk reporting practices. This can help to refine corporate governance guidelines and improve the effectiveness of recommendations and codes issued about boards of directors. In addition, the SEC, the European Securities and Markets Authority, as well as other international regulatory bodies can benefit from our evidence to shape their future legislation and recommendations about disclosure policies. Finally, this paper has implications for society, because the evidence demonstrates that the presence of women and ethnic minorities on boards is not only an ethical issue but also a business one. The issue of gender and ethnic minorities remains a controversial question in the US context, yet despite the regulatory and societal pressures, recent figures consistently demonstrate that women and ethnic minorities are clearly underrepresented in top US firms. Our findings therefore indicate that increased diversity is likely to have an important effect on board-specific decisions, which may positively influence firm outcomes. As a result, better disclosure practices and greater firm financial outcomes will also have a positive economic impact on capital markets or even national economies.

Our study has several limitations and presents interesting avenues for future inquiry. First, one common limitation of disclosure studies that use content analysis is sample size, as manual analysis requires considerable time and effort. However, there is
Voluntary risk disclosure on financial outcomes 
subjectivity when a machine is used to count words in relation to identifying keywords (Beattie and Thompson, 2007). Moreover, the sample size is adequate for the use of PLS technique (Roldán and Sánchez-Franco, 2012). Furthermore, we focus on risk disclosures given the ongoing debate surrounding the need to improve them. Researchers can also explore other kinds of information that might moderate the relationship analysed between board diversity and financial outcomes. We are also aware that we examine one particular industry in one specific context. Although the use of one industry may prevent bias, as disclosure practices might vary across industries, we must exercise caution when seeking to extrapolate the results. Nevertheless, given the regulatory, social and economic conditions that affected the US manufacturing industry and boards of directors in 2009, our setting does provide an appropriate scenario to understand the impact of board diversity and risk disclosures.

\section{Notes}

1. According to the US Bureau of Economic Analysis, manufacturing is an essential component of GDP. The manufacturing industry's contribution to US GDP in 2009 was about $12 \%$ and the current contribution remains similar (https://www.bea.gov/).

2. Detailed information about the design of this index can be found in Beretta and Bozzolan (2008, p. 344).

\section{References}

Abernathy, J.L., Herrmann, D., Kang, T. and Krishnan, G.V. (2013), "Audit committee financial expertise and properties of analyst earnings forecasts", Advances in Accounting, Vol. 29 No. 1, pp. 1-11.

Abraham, S. and Cox, P. (2007), "Analysing the determinants of narrative risk information in UK FTSE 100 annual reports”, The British Accounting Review, Vol. 39 No. 3, pp. 227-248.

Adams, R.B. and Ferreira, D. (2009), "Women in the boardroom and their impact on governance and performance”, Journal of Financial Economics, Vol. 94 No. 2, pp. 291-309.

Adams, C.A. and McNicholas, P. (2007), "Making a difference: sustainability reporting, accountability and organisational change", Accounting, Auditing and Accountability Journal, Vol. 20 No. 3, pp. 382-402.

Al-Akra, M. and Ali, M.J. (2012), "The value relevance of corporate voluntary disclosure in the MiddleEast: the case of Jordan", Journal of Accounting and Public Policy, Vol. 31 No. 5, pp. 533-549.

Allini, A., Manes Rossi, F. and Hussainey, K. (2016), "The board's role in risk disclosure: an exploratory study of Italian listed state-owned enterprises", Public Money and Management, Vol. 36 No. 2, pp. 113-120.

Bear, S., Rahman, N. and Post, C. (2010), "The impact of board diversity and gender composition on corporate social responsibility and firm reputation", Journal of Business Ethics, Vol. 97 No. 2, pp. 207-221.

Beattie, V. and Thompson, S.J. (2007), "Lifting the lid on the use of content analysis to investigate intellectual capital disclosures”, Accounting Forum, Vol. 31 No. 2, pp. 129-163.

Beretta, S. and Bozzolan, S. (2008), "Quality versus quantity: the case of forward-looking disclosure", Journal of Accounting, Auditing and Finance, Vol. 23 No. 3, pp. 333-376.

Bernile, G., Bhagwat, V. and Yonker, S. (2018), "Board diversity, firm risk, and corporate policies", Journal of Financial Economics, Vol. 127 No. 3, pp. 588-612.

Cabedo, J.D. and Tirado, J.M. (2004), "The disclosure of risk in financial statements", Accounting Forum, Vol. 28 No. 2, pp. 181-200. 
Cabedo, J.D. and Tirado, J.M. (2016), "Quantity and quality of risk information disclosed by Spanish firms: an analysis in different periods of the economic cycle", Revista de Contabilidad-Spanish Accounting Review, Vol. 19 No. 2, pp. 261-270.

Campbell, J.L., Chen, H., Dhaliwal, D.S., Lu, H.M. and Steele, L.B. (2014), “The information content of mandatory risk factor disclosures in corporate filings", Review of Accounting Studies, Vol. 19 No. 1, pp. 396-455.

Carter, D.A., D'Souza, F., Simkins, B.J. and Simpson, W.G. (2010), “The gender and ethnic diversity of US boards and board committees and firm financial performance", Corporate Governance: An

Voluntary risk disclosure on financial outcomes International Review, Vol. 18 No. 5, pp. 396-414.

Carter, D.A., Simkins, B.J. and Simpson, W.G. (2003), “Corporate governance, board diversity, and firm value", The Financial Review, Vol. 38 No. 1, pp. 33-53.

Castilla-Polo, F. and Ruiz-Rodríguez, C. (2017), "Content analysis within intangible assets disclosure: a structured literature review", Journal of Intellectual Capital, Vol. 18 No. 3, pp. 506-543.

Castro, I., Galán, J.L. and Casanueva, C. (2016), "Management of alliance portfolios and the role of the board of directors", Journal of Business Economics and Management, Vol. 17 No. 2, pp. 215-233.

Chin, W.W. (2010), "How to write up and report PLS analyses", Esposito Vinzi, V., Chin, W.W., Henseler, J. and Wang, H. (Eds), Handbook of Partial Least Squares: Concepts, Methods and Applications, Springer-Verlag, Berlin, pp. 655-690.

Committee of Sponsoring Organizations of the Treadway Commission (COSO) (2009), "Effective enterprise risk oversight: the role of the board of directors".

Dobler, M., Lajili, K. and Zéghal, D. (2011), "Attributes of corporate risk disclosure: an international investigation in the manufacturing sector", Journal of International Accounting Research, Vol. 10 No. 2, pp. 1-22.

Dutta, S. and Nezlobin, A. (2017), "Information disclosure, firm growth, and the cost of capital", Journal of Financial Economics, Vol. 123 No. 2, pp. 415-431.

Easton, P.D. (2004), "PE ratios, PEG ratios, and estimating the implied expected rate of return on equity capital", The Accounting Review, Vol. 79 No. 1, pp. 73-95.

Erhardt, N.L., Werbel, J.D. and Shrader, C.B. (2003), "Board of director diversity and firm financial performance", Corporate Governance, Vol. 11 No. 2, pp. 102-111.

Ernst and Young (2009), "The 2009 Ernst and Young business risk report".

Fairfax, L.M. (2010), "Board diversity revisited: new rationale, same old story", North Carolina Law Review, Vol. 89, pp. 855-886.

Freeman, R.E. (1984), Strategic Management: A Stakeholder Approach, Pitman Publishing, Boston.

Garcia-Meca, E. and Sanchez-Ballesta, J.P. (2011), "Firm value and ownership structure in the Spanish capital market", Corporate Governance: The International Journal of Business in Society, Vol. 11 No. 1, pp. 41-53.

Gaur, S.S., Bathula, H. and Singh, D. (2015), "Ownership concentration, board characteristics and firm performance: a contingency framework”, Management Decision, Vol. 53 No. 5, pp. 911-931.

Gordini, N. and Rancati, E. (2017), "Gender diversity in the Italian boardroom and firm financial performance", Management Research Review, Vol. 40 No. 1, pp. 75-94.

Gul, F.A., Srinidhi, B. and Ng, A.C. (2011), "Does board gender diversity improve the informativeness of stock prices?”, Journal of Accounting and Economics, Vol. 51 No. 3, pp. 314-338.

Hafsi, T. and Turgut, G. (2013), "Boardroom diversity and its effect on social performance: conceptualization and empirical evidence", Journal of Business Ethics, Vol. 112 No. 3, pp. 463-479.

Hail, L. and Leuz, C. (2009), "Cost of capital effects and changes in growth expectations around US cross-listings", Journal of Financial Economics, Vol. 93 No. 3, pp. 428-454. 
GM

35,5

Hair, J.F., Ringle, C.M. and Arstedt, M. (2011), "PLS-SEM: indeed a silver bullet", Journal of Marketing Theory and Practice, Vol. 19 No. 2, pp. 137-149.

Harjoto, M., Laksmana, I. and Lee, R. (2015), "Board diversity and corporate social responsibility", Journal of Business Ethics, Vol. 132 No. 4, pp. 641-660.

Hassan, M. (2009), "UAE corporations-specific characteristics and level of risk disclosure”, Managerial Auditing Journal, Vol. 24 No. 7, pp. 668-687.

Hassan, M.K. (2014), "Risk narrative disclosure strategies to enhance organizational legitimacy: evidence from UAE financial institutions", International Journal of Disclosure and Governance, Vol. 11 No. 1, pp. 1-17.

Hayes, A.F., Preacher, K.J. and Myers, T.A. (2011), "Mediation and the estimation of indirect effects in political communication research", Source Book for Political Communication Research: Methods, Measures, and Analytical Techniques, Vol. 23, pp. 434-465.

Helper, S., Krueger, T. and Wial, H. (2012), "Why does manufacturing matter? Which manufacturing matters?”, Metropolitan Policy Program Paper, pp. 1-53.

Hogan, R. and Huerta, D. (2019), "The impact of gender and ethnic diversity on REIT operating performance", Managerial Finance, Vol. 45 No. 1, pp. 72-84.

Iacobucci, D. and Duhachek, A. (2003), "Advancing alpha: measuring reliability with confidence", Journal of Consumer Psychology, Vol. 13 No. 4, pp. 478-487.

Jabeen, F. and Faisal, M.N. (2018), "Imperatives for improving entrepreneurial behavior among females in the UAE: an empirical study and structural model”, Gender in Management: An International Journal, Vol. 33 No. 3, pp. 234-252.

Jensen, M.C. and Meckling, W.H. (1976), "Theory of the firm: managerial behavior, agency costs and ownership structure", Journal of Financial Economics, Vol. 3 No. 4, pp. 305-360.

Jindal, S. and Kumar, M. (2012), "The determinants of HC disclosures of Indian firms", Journal of Intellectual Capital, Vol. 13 No. 2, pp. 221-247.

Kılıç, M. and Kuzey, C. (2016), "The effect of board gender diversity on firm performance: evidence from Turkey, gender in management", Gender in Management: An International Journal, Vol. 31 No. 7, pp. 434-455.

Kravet, T. and Muslu, V. (2013), "Textual risk disclosures and investors' risk perceptions", Review of Accounting Studies, Vol. 18 No. 4, pp. 1088-1122.

Krippendorff, K. (1980), Content Analysis: An Introduction to Its Methodology, Sage Publications, Beverly Hills, CA.

Lai, K.M., Srinidhi, B., Gul, F.A. and Tsui, J.S. (2017), "Board gender diversity, auditor fees, and auditor choice", Contemporary Accounting Research, Vol. 34 No. 3, pp. 1681-1714.

Lamber, R.A., Leuz, C. and Verrecchia, R.E. (2012), "Information asymmetry, information precision, and the cost of capital", Review of Finance, Vol. 16 No. 1, pp. 1-29.

Lending, C.C. and Vähämaa, E. (2017), "European board structure and director expertise: the impact of quotas", Research in International Business and Finance, Vol. 39, pp. 486-501.

Levi, M., Li, K. and Zhang, F. (2014), "Director gender and mergers and acquisitions", Journal of Corporate Finance, Vol. 28, pp. 185-200.

Linsley, P. and Shrives, P. (2006), "Risk reporting: a study of risk disclosures in the annual reports of UK companies", The British Accounting Review, Vol. 38 No. 4, pp. 387-404.

Li, J., Pike, R. and Haniffa, R. (2008), "Intellectual capital disclosure and corporate governance structure in UK firms", Accounting and Business Research, Vol. 38 No. 2, pp. 137-159.

Li, J., Zhao, F., Chen, S., Jiang, W., Liu, T. and Shi, S. (2017), "Gender diversity on boards and firms' environmental policy”, Business Strategy and the Environment, Vol. 26 No. 3, pp. 306-315.

Mensi-Klarbach, H. (2014), "Gender in top management research: towards a comprehensive research framework”, Management Research Review, Vol. 37 No. 6, pp. 538-552. 
Miller, T. and Triana, M.C. (2009), "Demographic diversity in the boardroom: mediators of the board diversity-firm performance relationship", Journal of Management Studies, Vol. 46 No. 5, pp. 755-786.

Moumen, N., Othman, H.B. and Hussainey, K. (2015), "The value relevance of risk disclosure in annual reports: evidence from MENA emerging markets", Research in International Business and Finance, Vol. 34, pp. 177-204.

National Association of Corporate Directors (NACD) (2009) "Report of the NACD Blue Ribbon Commission on Risk Governance: Balancing Risk and Reward".

Voluntary risk disclosure on financial outcomes

Neifar, S. and Jarboui, A. (2017), "Corporate governance and operational risk voluntary disclosure: evidence from Islamic banks", Research in International Business and Finance, Vol. 46.

Nielsen, S. and Huse, M. (2010), "The contribution of women on boards of directors: going beyond the surface", Corporate Governance: An International Review, Vol. 18 No. 2, pp. 136-148.

Ntim, C.G., Lindop, S. and Thomas, D.A. (2013), "Corporate governance and risk reporting in South Africa”, International Review of Financial Analysis, Vol. 30, pp. 363-383.

Oliveira, J., Rodrigues, L.L. and Craig, R. (2013), "Public visibility and risk-related disclosures in Portuguese credit institutions", The Journal of Risk, Vol. 15 No. 4, pp. 57-90.

Pfeffer, J. and Salancik, G. (1978), The External Control of Organizations: A Resource-Dependence Perspective, Harper and Row, New York, NY.

Plumlee, M., Brown, D., Hayes, R.M. and Marshall, R.S. (2015), "Voluntary environmental disclosure quality and firm value: further evidence", Journal of Accounting and Public Policy, Vol. 34 No. 4, pp. 336-361.

Pucheta-Martínez, M.C., Bel-Oms, I. and Olcina-Sempere, G. (2016), "Corporate governance, female directors and quality of financial information”, Business Ethics: A European Review, Vol. 25 No. 4, pp. 363-385.

Quintana-García, C. and Benavides-Velasco, C.A. (2016), "Gender diversity in top management teams and innovation capabilities: the initial public offerings of biotechnology firms", Long Range Planning, Vol. 49 No. 4, pp. 507-518.

Reguera-Alvarado, N., de Fuentes, P. and Laffarga, J. (2017), "Does board gender diversity influence financial performance? Evidence from Spain”, Journal of Business Ethics, Vol. 141 No. 2, pp. 337-350.

Reinartz, W., Haenlein, M. and Henseler, J. (2009), "An empirical comparison of the efficacy of covariance-based and variance-based SEM", International Journal of Research in Marketing, Vol. 26 No. 4, pp. 332-344.

Rhode, D.L. and Packel, A.K. (2010), "Diversity on corporate boards: how much difference does difference make?”, Delaware Journal of Corporate Law, Vol. 39, p. 377.

Roldán, J.L. and Sánchez-Franco, M.J. (2012), "Variance-based structural equation modeling: guidelines for using partial least squares in information systems research", Research Methodologies, Innovations and Philosophies in Software Systems Engineering and Information Systems, pp. 193-221.

Sappal, S. (2016), "Ethnic diversity of boards of US companies: business sustainability and group dynamics".

Satta, G., Parola, F., Profumo, G. and Penco, L. (2015), "Corporate governance and the quality of voluntary disclosure: evidence from medium-sized listed firms", International Journal of Disclosure and Governance, Vol. 12 No. 2, pp. 144-166.

Securities Exchange Commission (2009), "No, S. R. 33-9089. Proxy Disclosure Enhancements (Dec. 16, 2009)".

Srinidhi, B., Gul, F.A. and Tsui, J. (2011), "Female directors and earnings quality", Contemporary Accounting Research, Vol. 28 No. 5, pp. 1610-1644. 
GM

35,5

Taylor, A., MacKinnon, D. and Tein, J. (2008), “Tests of the three-path mediated effect”, Organizational Research Methods, Vol. 11 No. 2, pp. 241-269.

Tenenhaus, M., Esposito-Vinzi, V., Chatelin, Y. and Lauro, C. (2005), "PLS path modeling", Computational Statistics and Data Analysis, Vol. 48 No. 1, pp. 159-205.

Terjesen, S., Couto, E.B. and Francisco, P.M. (2016), "Does the presence of independent and female directors impact firm performance? A multi-country study of board diversity", Journal of Management and Governance, Vol. 20 No. 3, pp. 447-483.

Upadhyay, A. and Zeng, H. (2014), "Gender and ethnic diversity on boards and corporate information environment", Journal of Business Research, Vol. 67 No. 11, pp. 2456-2463.

Walt, N. and Ingley, C. (2003), "Board dynamics and the influence of professional background, gender and ethnic diversity of directors", Corporate Governance, Vol. 11 No. 3, pp. 218-234.

Wang, Z., Ali, M. and Al-Akra, M. (2013), "Value relevance of voluntary disclosure and the global financial crisis: evidence from China”, Managerial Auditing Journal, Vol. 28 No. 5, pp. 444-468.

Westphal, J.D. and Bednar, M.K. (2005), "Pluralistic ignorance in corporate boards and firms' strategic persistence in response to low firm performance", Administrative Science Quarterly, Vol. 50 No. 2, pp. 262-298.

Williams, J. and MacKinnon, D.P. (2008), "Resampling and distribution of the product methods for testing indirect effects in complex models", Structural Equation Modeling: A Multidisciplinary Journal, Vol. 15 No. 1, pp. 23-51.

Zhang, J.Q., Zhu, H. and Ding, H. (2013), "Board composition and corporate social responsibility: an empirical investigation in the post Sarbanes-Oxley era", Journal of Business Ethics, Vol. 114 No. 3, pp. 381-392.

\section{Corresponding author}

Nuria Reguera-Alvarado can be contacted at: nreguera@us.es

For instructions on how to order reprints of this article, please visit our website: www.emeraldgrouppublishing.com/licensing/reprints.htm Or contact us for further details: permissions@emeraldinsight.com 